\title{
RECENT DEVELOPMENTS \\ CONCERNING ACCREDITING \\ AGENCIES IN POSTSECONDARY \\ EDUCATION
}

\author{
JEFFREY C. MARTIN*
}

\section{INTRODUCTION}

The federal government relies on a system of private accreditation in determining which postsecondary institutions are eligible to participate in federal student aid programs. Three checkpoints must be cleared to establish eligibility: federal certification of financial and administrative capability; state licensing or approval to operate in a state; and accreditation by a recognized accrediting agency. ${ }^{1}$

Under this system, the accrediting agency is typically the sole arbiter of whether the training or education offered by an institution is of sufficient quality to authorize spending federal student aid money there. Thus, accrediting agencies play a critical role in the effort to secure sound stewardship of federal monies spent on higher education. For this reason, the U.S. Department of Education and its predecessor, the Office of Education, have for many years engaged in limited review of accrediting agencies to determine which ones to designate as reliable authorities and hence entrust with "gatekeeping" authority over institutional access to federal student aid funds.

Over the past few years, the role of postsecondary accrediting agencies as federal gatekeepers has attracted unprecedented public scrutiny. Two distinct phenomena triggered this attention: (1) the magnitude of student loan defaults, and the related and larger problem of certain vocational or trade schools, primarily proprietary schools, using federal monies to provide overpriced and inadequate training that fails to equip their students with the skills to perform the trained-for vocation, leading to calls for greater public accountability of accrediting agencies, ${ }^{2}$ and $(2)$ in the collegiate sector, the insistence of certain accrediting agencies wielding their federal clout that the colleges, universities,

Copyright $\odot 1995$ by Law and Contemporary Problems

Partner, Shea \& Gardner, Washington, D.C.; Special Adviser to the Secretary of Education, April-June 1991; General Counsel of the U.S. Department of Education, July 1991-December 1992.

The views expressed herein are the author's own and not necessarily those of the Department of Education or anyone else who serves or has served at the Department.

1. See 20 U.S.C. § 1099c(a) (Supp. IV 1992).

2. See, e.g., Permanent Subcomm. On Investigations, Senate Comm. On Governmental AfFairs, Abuses in Federal Student Aid Programs, S. ReP. No. 58, 102d Cong., 1st Sess. 16-20, 26-28 (1991) [hereinafter NUNN COMMITTEE REPORT]. 
and seminaries they accredit become more demographically diverse in their student bodies, faculties, and governing boards, and to prescribe gender or racial requirements.

As a result, the relationship between private voluntary accrediting agencies and federal eligibility has itself been questioned. Proposals for reform have ranged from removing the federal eligibility consequences from the decisions of accrediting agencies to requiring greater accountability of accrediting agencies to federal interests, and from facilitating competition among accrediting agencies to prohibiting such competition.

Part II of this article briefly discusses the background of Department of Education recognition of accrediting agencies in higher education. It explains how the function of federal recognition has evolved from public information to regulation. The article then addresses how in 1991 and 1992 the Department addressed the two problems of inadequate rigor in vocational school accreditation and intrusive accreditation review in the collegiate sector. Specifically, part III analyzes the Department of Education's handling of the renewal recognition petition of a large, respected, and well-established regional accrediting agency, Middle States, which undertook to require institutions in its region to meet certain racial and gender diversity requirements as a condition of accreditation. Part IV then discusses whether competition among accreditors would be a desirable way to preserve institutional autonomy. Part $\mathrm{V}$ examines the Department's efforts to increase scrutiny of the accrediting agencies for proprietary schools by focusing on an agency's substantive decisionmaking record, not merely its processes and procedures. Part VI discusses proposals that have been made over time to divorce federal eligibility from accreditation, including the House Education and Labor Committee's 1992 recommendation to eliminate accreditation as a requirement for eligibility. Part VII analyzes how Congress has transformed the relationship between educational accrediting agencies and the federal government in the Higher Education Amendments of 1992 (the "1992 HEA"), ${ }^{3}$ particularly evaluating the 1992 HEA's approach to the problems of intrusive collegiate accrediting agencies and lax vocational school accreditation. In addressing these issues, part VII also discusses certain constitutional issues that may arise as these problems are faced under the 1992 HEA.

There are two principal categories of accrediting agencies. Institutional agencies accredit entire institutions, such as all degree-granting colleges in a geographic region, or to take a narrower example, all bible colleges of a certain theological perspective. Programmatic accrediting agencies accredit particular programs that are generally part of broader institutions. In general, federal eligibility is determined by the institutional accrediting agencies. It is thus the

3. Pub. L. No. 102-325, 106 Stat. 448 (codified as amended in scattered sections of 11, 20, 25, and 42 U.S.C.). The Department has recently adopted regulations implementing the accreditation provisions of the 1992 HEA. 34 C.F.R. $\$ 602$ (1994). These regulations will be mentioned at times, but a full discussion of them is beyond the scope of this article. 
institutional agencies which usually present issues about the use of private associations to serve federal regulatory purposes. For that reason, this article deals principally with institutional accrediting agencies.

II

\section{HISTORICAL BACKGROUND OF THE DEPARTMENT OF EDUCATION'S RECOGNITION OF ACCREDITING AGENCIES}

At least since the early 20th century, the United States Office of Education (now the Department of Education) has published lists of accredited institutions of higher education, making informal determinations as to which accrediting agencies' decisions to recognize in listing accredited institutions. ${ }^{4}$ One of the Office's earliest functions was to gather and disseminate education facts and statistics, and these lists were simply part of that responsibility. ${ }^{5}$ They had no regulatory consequences. ${ }^{6}$

With the enactment of the Veterans' Readjustment Assistance Act of 1952 (the "VRAA"), which was designed to reduce abuses, particularly by proprietary schools, of veterans' educational benefits arising out of the Servicemen's Readjustment Act of $1944,{ }^{8}$ the Commissioner of Education's recognition of accrediting agencies took on regulatory consequences. ${ }^{9}$ Commencing with the VRAA, the federal government began to rely on the already well-established system of voluntary accrediting agencies to determine which institutions were of sufficient quality to participate in federal student aid programs. Enactment of the Higher Education Act of 1965 (the "HEA"), with its establishment of broad federal student aid programs extending beyond veterans, increased the importance of accreditation in determining institutional eligibility for student aid.

When the federal government determined in 1952 and 1965 to provide funds for students to go to college or postsecondary training school, it faced the

4. For a thorough treatment of the origins of educational accreditation and its relationship to federal eligibility, see HAROLD ORLANS, PRIVATE ACCREDITATION AND PUBLIC ELIGIBILITY 6-14, 35 . 49 (1975). Professor Finkin has also described the context in which voluntary accreditation in higher education took root. Matthew W. Finkin, The Unfolding Tendency in the Federal Relationship to Private Accreditation in Higher Education, 57 LAW \& CONTEMP. PROBS. 89 (Autumn 1994).

5. ORLANS, supra note 4 , at 7-8.

6. Id. By 1948 , the Office had published criteria for recognition of accrediting agencies, including a criterion that "[i]n principle the Office of Education should recognize only one accrediting agency in any given professional field." THERESA BIRCH WILKINS, FEDERAL SECURITY AGENCY, ACCREDITED HIGHER INSTITUTIONS 2-3 (1949), cited in ORLANS, supra note 4, at 39 n.4.

7. Ch. 875,66 Stat. 663 (codified as amended in scattered sections of 38 U.S.C.).

8. Ch. 268,58 Stat. 284 (codified as amended at 38 U.S.C. $\$ \S 1801-1851$ ).

9. See S. REP. No. 1824, 82nd Cong., 2d Sess. (1952). Professor Finkin has more fully described the advent of federal reliance on voluntary accrediting agencies for regulatory purposes. Matthew W. Finkin, Federal Reliance on Voluntary Accreditation: The Power to Recognize as the Power to Regulate, 2 J.L. \& EDUC. 339 (1979); Matthew W. Finkin, Reforming the Federal Relationship to Educational Accreditation, 57 N.C. L. REV. 379, 380-85 (1979); Finkin, supra note 4, at 93-107.

10. Pub. L. No. 89-329, 79 Stat. 1219 (codified as amended in scattered sections of 20 and 42 U.S.C.). 
question of defining for federal eligibility purposes what constitutes a college or postsecondary training institute. Congress took the approach of requiring federal education officials to defer to legitimate and respected accrediting agencies as the authorities on the subject. Specifically, to protect the federal interest in ensuring that federal student aid dollars are not wasted at postsecondary institutions that do not provide the quality of training or education they purport to provide, the Commissioner of Education (now Secretary of Education) was statutorily charged with determining which accrediting agencies are "reliable authorities" as to the quality of education or training offered at postsecondary institutions. ${ }^{11}$ In general, only institutions accredited by agencies recognized by the Secretary could participate in federal student aid programs. That remains the case under current law. ${ }^{12}$ In other words, the Secretary of Education accredits the accreditors. But under the Department of Education's organizational statute, no "control" is to be exercised by the Department over any school or accrediting agency, except to the extent authorized by law. ${ }^{13}$ This is in keeping with the strong tradition in the United States that education is primarily a local and state responsibility, not a federal one.

The government's reliance on voluntary accrediting agencies for federal eligibility purposes has changed the agencies. Since the recognition of accrediting agencies assumed regulatory consequences, the Department has promulgated and repeatedly revised regulations governing the Commissioner's or Secretary's recognition of accrediting agencies. ${ }^{14}$ With each change to the federal recognition process for accrediting agencies, the federal government has influenced the way private postsecondary accrediting agencies perform their jobs because federal recognition has been considered essential or at least desirable by most agencies. The 1992 reauthorization of the HEA made the federal government's recognition of accrediting agencies substantially more regulatory in nature. As will be discussed below, the 1992 legislation requires recognized agencies to address subjects that have not traditionally been reviewed by many accrediting agencies, such as institutional default rates, federal program compliance, student outcomes, and student complaints. ${ }^{15}$

In addition to recognizing agencies for purposes of federal eligibility, until 1988 the Department recognized accrediting agencies that did not make decisions with federal regulatory consequences, such as those in the elementary and secondary education areas. Federal recognition in these cases was merely a "seal of approval." In 1988, Secretary of Education William Bennett decided not to continue Department of Education review and recognition of accrediting

11. Id. $\S 435,79$ Stat. at $1247-49$.

12. E.g., 20 U.S.C. $\S \S 1099$ b, 1099c, 1141(a) (Supp. IV 1992).

13. Id. $\S 3403(\mathrm{~b})(1988)$.

14. 17 Fed. Reg. 8929 (1952); 34 Fed. Reg. 643 (1969); 39 Fed. Reg. 30,042 (1974); 34 C.F.R. § 602 (1988). Recently, the Department adopted new regulations to implement the accreditation provisions of the 1992 HEA. 34 C.F.R. $\$ 602$ (1994).

15. See infra text accompanying notes $93-95,128-29$. 
agencies for elementary and secondary schools, since there is no connection between accreditation of such schools and eligibility for federal aid. ${ }^{16}$ The 1992 HEA codifies and extends this decision, limiting the Secretary's recognition jurisdiction to agencies that accredit institutions of higher education for purposes of federal program eligibility. ${ }^{17}$

Department of Education recognition of postsecondary accrediting agencies has also had state law consequences, as many state laws condition licensing of professions on graduation from institutions or programs accredited by a Department-recognized accrediting agency. ${ }^{18}$ These state laws need to be revisited in light of the 1992 HEA. As the Department, consistent with the 1992 HEA, limits its role to agencies that determine federal eligibility, it will no longer list many of the specialized or programmatic agencies on which the states have, in reliance on the federal recognition of such agencies, conferred the authority to determine entry to various professions. An alternative form of professional screening will need to be found by the states. ${ }^{19}$

16. 34 C.F.R. $\S \S 602-603$ (1988).

17. 20 U.S.C. $\$ 1099$ b(m) (Supp. IV 1992).

18. See, e.g., Sherman College of Straight Chiropractic v. American Chiropractic Ass'n, Inc., 654 F. Supp. 716, 719 (N.D. Ga. 1986).

19. Several state laws also relate professional licensing to graduation from an institution accredited by an agency recognized by the Council on Postsecondary Accreditation ("COPA"), a private nonprofit umbrella group for postsecondary accrediting agencies. Those laws will need to be revised as well. One product of heightened public dissatisfaction with postsecondary accrediting, particularly in the proprietary sector, is the demise of COPA, the board of which in April 1993 voted to dissolve effective December 31, 1993. Carol Innerst, College Accreditors' Overseer Votes Itself Out of Existence, WASH. TIMES, Apr. 8, 1993, at A5. One major factor in COPA's demise was that the regional accrediting agencies were uncomfortable being part of the same lobbying and self-regulatory association as the trade school agencies. Samuel Weiss, Under Fire, Accreditors of Colleges Break Ranks, N.Y. TIMES, Feb. 24, 1993, at A17. There was also a sense that COPA was too weak to be an effective selfregulatory vehicle for accrediting agencies. Innerst, supra. Never in COPA's 19-year history had it dropped an agency from membership. Id. Governmental pressure on agencies to deal with defaults, and the Middle States controversy, may also have played a role in the regionals' dissatisfaction with being represented by COPA. Id. A successor institution, the Commission on Recognition of Postsecondary Accreditation, has been formed to carry out the evaluation and recognition of accrediting agencies previously undertaken by COPA. COMMISSION ON RECOGNITION OF POSTSECONDARY ACCREDITATION, RECOGNIZED ACCREDITING AGENCIES AND SUPPORTERS OF ACCREDITATION 3 (1994). 

governing board of an institution as a condition of accreditation. ${ }^{21}$ The initial adoption of these standards provoked little controversy. Many member institutions viewed them as a simple affirmation of the basic American commitment to equality of opportunity and sensitivity to the many cultural backgrounds of the nation's people. However, Middle States's subsequent application of these standards provoked a firestorm of media and governmental scrutiny seldom accorded accrediting decisions.

Middle States's decision to condition accreditation on satisfaction of diversity criteria came under scrutiny in the fall of 1990 , when its actions respecting Baruch College of the City University of New York and Westminster Theological Seminary came to public attention. In the Baruch College case, Middle States deferred reaccreditation of Baruch because, among other things, Baruch's percentage of minority faculty and administrators was deemed too low, even though Baruch's percentage of minority faculty members (eighteen percent) was higher than that found in many other institutions accredited by Middle States. ${ }^{22}$ Middle States did not specify a percentage requirement, but it firmly indicated that eighteen percent was not good enough. ${ }^{23}$ Middle States's action ultimately contributed to the resignation of Baruch's president. ${ }^{24}$ In the Westminster case, Middle States threatened to withdraw the school's accreditation because it resisted including a woman on its governing board due to its Calvinist theology, which held that only ordained elders or ministers should be on the governing board and that only men should be ordained. ${ }^{25}$ In both cases, Middle States found that the institutions in question were of high academic quality but that their failure to satisfy diversity criteria prevented their reaccreditation by Middle States. ${ }^{26}$

2. Secretary Alexander's Initial Decision. On April 11, 1991, Education Secretary Lamar Alexander remanded Middle States's petition for renewal of recognition to the National Advisory Committee on Accreditation and Institutional Eligibility ${ }^{27}$ for it and Department staff to consider and advise

21. Commission on Higher Educ., Middle States Ass'N of Colleges and Sch., CHARACTERISTICS OF EXCELLENCE IN HIGHER EDUCATION: STANDARDS FOR ACCREDITATION 25, 32 (rev. ed. 1990) [hereinafter CHARACTERISTICS].

22. E.g., James H. Daughdrill, Jr., Diversity at the Service of Politics; Colleges Are Being Forced Into Narrow Gender and Race Quotas, L.A. TiMES, Dec. 16, 1991, at B5 (citing Joel Seagall, president of Baruch College, at the time of Middle States's adverse action); Jim Sleeper, The Policeman of Diversity; How the Middle States Accreditors Threaten Academic Freedom, WASH. POST, June 30, 1991, at C1.

23. Daughdrill, supra note 22; Sleeper, supra note 22.

24. E.g., Samuel Weiss, Baruch Offers Plan Seeking Racial Blend, N.Y. TIMES, May 3, 1990, at B1.

25. Decision of the Secretary of Education Remanding Petition for Renewal of Recognition of the Commission on Higher Education of the Middle States Association of Colleges and Schools (Apr. 11, 1991) (on file with author) [hereinafter Decision of the Secretary].

26. Id. at 2; Sleeper, supra note 22.

27. This Committee, established pursuant to 20 U.S.C. $\$ 1145$ (Supp. II 1990), advised the Secretary on accrediting agencies' petitions for recognition. Under the $1992 \mathrm{HEA}$, the Committee is reconstituted as the Committee on Institutional Quality and Integrity, with responsibility for advising the Secretary on all three components of the triad. Id. $\S 1145$ (Supp. IV 1992). The recently adopted regulations under the 1992 HEA, which took effect on July 1, 1994, also commit to this Committee, or a 
whether Middle States's actions regarding Baruch College and Westminster undermined Middle States's reliability and otherwise indicated noncompliance with the Department's recognition regulations. ${ }^{28} \mathrm{He}$ also voiced his concern that Middle States was wielding federal power in a manner that threatened academic freedom and diversity among institutions. ${ }^{29} \mathrm{He}$ further observed that the Department of Education, not accrediting agencies, has been charged with enforcing the federal civil rights statutes applicable to recipients of federal education monies, ${ }^{30}$ and he noted that an accrediting agency's incorrect imposition of race- or gender-based admissions or hiring procedures could itself lead to violations of federal civil rights laws. ${ }^{31}$

3. The Legal Objections to Alexander's Remand Decision. Middle States questioned the legal basis for Secretary Alexander's decision. Many in the Washington higher education establishment, including the President of the American Council of Education and the Executive Director of the Council on Postsecondary Accreditation, backed Middle States's position questioning the Secretary's authority. ${ }^{32}$ They pointed out that under section 103 of the Department of Education Organizational Act (the "DEOA"), the Secretary must not "exercise any direction, supervision or control over . . . any accrediting agency ... except to the extent authorized by law"33 and argued that the Secretary's actions violated that prohibition. ${ }^{34}$ They viewed the Secretary's action as a threat to the voluntary nature of accrediting agencies, which in their view should be free to set their own standards without being second-guessed by government. ${ }^{35}$

In my view, there was no substantial legal argument that Secretary Alexander's April 11, 1991 decision on Middle States ran afoul of section 103 of the DEOA. The HEA required the Secretary of Education to recognize only those accrediting agencies that he or she determined to be "reliable authorities" as to the "quality of training" or education offered by the institutions reviewed

subcommittee thereof, initial decisions on whether to limit, suspend, or terminate recognition of an agency before completion of its previously granted recognition period. 34 C.F.R. $\$ 602.14$ (1994). Thus, this advisory committee is slated to become more of an adjudicatory tribunal.

28. See Decision of the Secretary, supra note 25, at 2-3.

29. Id. at 2.

30. Id. at 3; cf. 53 Fed. Reg. $25,095,25,095-96$ (July 1, 1988) (removing requirement directing accrediting agencies to examine nondiscrimination at schools in light of Secretary Bennett's belief that "the issue is covered adequately in Federal civil rights legislation").

31. See Decision of the Secretary, supra note 25 , at 3.

32. Robert Atwell, Remarks at Meeting of National Advisory Committee on Accreditation and Institutional Eligibility (Nov. 21, 1991); COPA, Statement on Middle States presented at Meeting of National Advisory Committee on Accreditation and Institutional Eligibility (Nov. 21, 1991); see also Commission of Institutions of Higher Education, North Central Association, Special Insert to Fall 1991 Briefing 3 (on file with author) (questioning Secretary Alexander's April 11, 1991 decision as going "beyond his limited statutory authority").

33. 20 U.S.C. \& 3403(b) (1988).

34. See authorities cited supra note 32.

35. See authorities cited supra note 32. 
by the agency seeking recognition. ${ }^{36}$ Section 103 thus authorizes Secretarial review of an accrediting agency's practices for purposes of determining whether to recognize the agency as reliable. That authority formed the exclusive and sufficient basis for the questions and concerns raised in Secretary Alexander's initial Middle States decision.

There was no doubt that under section 103 of the DEOA the Secretary of Education could not direct Middle States or any other accrediting agency to change its diversity standards or their application. No such action was ever taken, intimated, or considered by the Department. The only question was whether the agency should be listed by the Secretary as reliable.

Middle States, by threatening to withdraw accreditation of institutions like Westminster and Baruch on grounds that did not undercut the accrediting agency's own conclusion that the institutions were of high quality, raised serious questions about its reliability for federal "gatekeeping" purposes. As will be discussed in detail below, Middle States's actions also raised constitutional concerns about lending the coercive power of the federal government to accrediting agencies that were at least arguably infringing on institutional academic freedom.

4. The Policy Debate Over the Appropriateness of Federal Intervention. The regional accrediting agencies and many of the Washington-based representatives of the higher education community also objected to the Department's scrutiny of Middle States on policy grounds. They argued that governmental oversight of voluntary accrediting agencies' practices was intrusive and would undermine a source of the strength of the nation's higher education system: its relative freedom from government control.

Several months after his initial remand decision, Secretary Alexander spoke to the National Advisory Committee on Accreditation and Institutional Eligibility regarding Middle States's handling of the Baruch and Westminster cases. ${ }^{37}$ His remarks make clear the perspective underlying his remand decision. Secretary Alexander had no doubt that diversity at colleges and universities was an important and desirable objective, but he suggested that diversity was a matter for the governing authorities at the institution itself to address:

[T] he issue that I found on my desk when I arrived here in March as Secretary of Education, whether I should take any action as a result of an apparent attempt by the Middle States Accrediting Association to impose its definition of diversity on its member institutions, did not arise within me as a question of whether or not diversity is a good thing. For me diversity is more than a good thing. It is what gives America its energy, its uniqueness. ...

I would fully expect most American colleges and universities to seek to create on their campus an intellectual environment that reflects America's diversity, to try to

36. 20 U.S.C. $\S \S 1085,1088,1141$ (1988).

37. See Secretary Lamar Alexander, Remarks at Meeting of the National Advisory Committee on Accreditation and Institutional Eligibility (Nov. 12, 1991) (transcript on file with author). 
attract and retain a campus population of many different experiences, opinions, backgrounds and cultures. But what surprised me, and I'm using this word carefully because it did surprise me, and I have been chairman of a university, chairman of the board for eight years and president for three years, and I did not know that it was the job of an accrediting agency to define for a university what its diversity ought to be. Why is that not the job of a college president or its board or the faculty or the entire university community? ${ }^{38}$

In Alexander's view, while Middle States's assumption of the role of diversity arbiter seemed questionable, this did not necessarily mean that the government should intervene to protect the schools from an overbearing accreditor:

[Yet] [e]ven if the actions of Middle States in these cases are inappropriate, is it any business of the Secretary of Education? My instincts tell me that ordinarily it should not be. Ordinarily I would not think that the Secretary of Education of the moment has any more business defining for Middle States what its attitudes toward diversity ought to be than Middle States does defining for Baruch College what its diversity standards ought to be. Ordinarily, I'd be persuaded by the argument that colleges and universities voluntarily join accrediting associations, and if they want to have diversity defined for them by that association, then that is their business. ${ }^{39}$

So why did Secretary Alexander intervene? He explained that the shibboleth that accrediting agencies are merely voluntary membership organizations ignores the reality that the federal government has given accreditors federal power to determine access of higher education institutions to federal monies-indeed, in some cases, monopolistic power:

[T] he existence of such a powerful relationship between federal financial aid and accreditation has distorted this picture. If a college is not accredited, it can't accept a student with a federal grant or loan. So when Middle States or some other accrediting agency makes even a suggestion to a college about what its diversity ought exactly to be, that suggestion carries with it the clout of the federal government ... . In addition, sometimes department regulations, our regulations, have been read to say that an accrediting agency could not have a competitor unless the accrediting agency approves. ${ }^{40}$

Thus, the policy justification for federal oversight of overly perscriptive or intrusive standards by accrediting agencies seeking the government's recognition is simple: The government should not arm a private actor with decisive federal authority and then disclaim all responsibility if that actor exercises the federal power so conferred to infringe legitimate institutional autonomy.

5. The Constitutional Context: Turning the Supreme Court's Approval of A Race-Conscious "Diversity" Policy On Its Head. There is a certain irony in Middle States's approach to championing diversity, given the origins of that word in the development of affirmative action law. "Diversity" as a shorthand for demographic balancing appears to have evolved from and acquired considerable currency as a result of Justice Powell's different use of that word

38. Id. at 12-13.

39. Id. at 14.

40. Id. at 15 . 
in Bakke. ${ }^{41}$ Justice Powell's decisive opinion in Bakke held unconstitutional the University of California at Davis medical school's set-aside of a fraction (sixteen percent) of the admission slots to members of specified racial minorities. But he indicated that race-conscious admissions could be justified under both the Constitution and Title VI of the Civil Rights Act of 1964 as an exercise by the university's first amendment freedom to consider in admissions decisions the applicants' backgrounds in order to enrich the academic life of the campus. As an example, he cited Harvard College's policy of seeking students from a diversity of backgrounds. ${ }^{42}$ Explicit consideration of a student's race as part of a broad diversity policy can be justified by the college's interest in selecting students who, because of their background, will contribute the most to a rich and robust exchange of ideas on campus. ${ }^{43}$ But Justice Powell insisted that the Constitution and Title VI require that all students be individually assessed for their contribution to that goal and that the objective of raceconscious admissions be this intellectual and academic goal, not simply racial balance for its own sake. ${ }^{44}$

Middle States, in applying its diversity standards at Baruch and Westminster, was seeking a purely demographic result-a woman on the board at a Calvinist seminary, greater than eighteen percent minority faculty at an urban college. Unlike Justice Powell, who insisted that a constitutional diversity program must assess all students as individuals for what they would contribute to the institution's goal of intellectual diversity, Middle States focused exclusively on racial and gender diversity. Even more incongruously, Justice Powell founded his approval of race-conscious admissions on the university's first amendment freedom to chart its own course in seeking academic objectives. ${ }^{45}$ By contrast, Middle States's diversity standards were used to dictate objectives and strategies to academic institutions under the threat of denial of federal aid. Its actions threatened academic freedom.

Furthermore, Middle States's efforts to advance diversity within institutions ran counter to preservation of diversity among higher education institutions. On campuses across this country, faculties and administrators spend a great deal of time and effort determining what, if any, forms of affirmative action are appropriate for their institutions. An accrediting agency, as a group of informed outsiders, may be in a position to offer advice on such matters. Predicating accreditation and federal eligibility upon following the agency's advice, however, could pose a distinct threat to the institution's academic freedom.

41. Regents of the Univ. of Cal. v. Bakke, 438 U.S. 265 (1978).

42. Id. at $316-17$.

43. Id. at 315-18.

44. See id. at 315 ("The diversity that furthers a compelling state interest encompasses a far broader array of qualifications and characteristics of which racial or ethnic origin is but a single though important element. Petitioner's special admissions program, focused solely on ethnic diversity, would hinder rather than further attainment of genuine diversity." (emphasis in original)).

45. See, e.g., id. at 312; Keyishian v. Board of Regents, 385 U.S. 589, 603 (1967). 
6. The Denouement. The membership of Middle States, after the Secretary's initial remand decision, decided to amend Middle States's diversity standards to provide that each member school is free to define diversity for itself and that the agency's diversity standards are not mandatory conditions for accreditation. ${ }^{46}$ Following that change of direction, Secretary Alexander renewed Middle States's recognition for four years. ${ }^{47}$

Since Secretary Alexander's final Middle States decision, and the agency's voluntary change in criteria, no complaints about the diversity issue among the schools reviewed by Middle States have come to public attention. Application of diversity standards has continued to be controversial in the Western Association, the regional accrediting association for the western United States, particularly but not exclusively with respect to religiously affiliated schools. ${ }^{48}$ The North Central Association has adopted general policies supportive of demographic diversity, but has not, so far as I am aware, been so prescriptive as to threaten institutional autonomy. ${ }^{49}$ And certain specialized agencies continue to pursue diversity issues in a controversial manner. For example, the Association of American Law Schools (the "AALS") requires that a member school "shall seek to have a faculty, staff and student body which are diverse with respect to race, color and sex," while simple equal opportunity is required with respect to religion, disability, age, national origin, and sexual orientation..$^{50}$

Although the AALS's approach to diversity is of serious concern to some in the academic world ${ }^{51}$ the federal government has less reason to be concerned with the dictates of specialized or programmatic accreditors like the AALS since, in general, federal program eligibility is determined by the institutional accreditors not the specialized program accreditors. ${ }^{52}$ Specialized accreditors may, however, wield very significant state authority. For example,

46. Approved Changes in Characteristics of ExCELlenCE iN Higher EduCATION effective December 13, 1991, in CHARACTERISTICS, supra note 21.

47. Decision of the Secretary of Education on the Petition for Renewal of Recognition Submitted by the Commission on Higher Education of the Middle States Association of Colleges and Schools (Apr. 14, 1992) (on file with author).

48. Objections by Stanford and other major universities to the Western Association's diversity standards recently led the Western Association to back off from an aggressive role in policing diversity. K.L. Billingsley, Colleges Back Off "Diversity" Bridle of Accrediting Agency, WASH. Times, Aug. 13, 1994, at A4.

49. See North Cent. Ass'N, HandBook of AcCreditation 1993-1994, at 36 (Working Draft) (adopting statement on "Access, Equity and Diversity" as part of the association's integrity criterion) (on file with author).

50. Association OF AMERICAN LAw SCHOOLS 1993 HANDBoOK, § 6.4.

51. E.g., Paul D. Carrington, Diversity!, 1992 UTAH L. REV. 1105.

52. Where specialized accrediting agencies accredit specialized schools that are stand-alone institutions instead of components of a broader college or university, the decisions of such accreditors may have federal eligibility or regulatory consequences. Under the 1992 HEA, the Secretary of Education reviews only those accrediting agencies whose decisions have federal regulatory consequences. See supra text accompanying note 17 . Thus, the regulations provide that the Secretary will recognize only accrediting agencies that accredit higher education institutions or programs where such accreditation is required to enable them to participate in HEA programs or other federal programs. 59 Fed. Reg. 22,254 (1994) (to be codified at 34 C.F.R. $\$ 602.1$ ). 
most state supreme courts require graduation from a school accredited by the American Bar Association as a condition for admission to the bar. ${ }^{53}$ Other professions also link licensing requirements to graduation from accredited programs. Where significant governmental consequences flow from the decisions of accreditors, their decisions must respect the institution's academic freedom-not only on diversity but on the many other subjects by which colleges define themselves-or face substantial challenge in the courts under the First Amendment. ${ }^{54}$

\section{IV}

\section{Competition As A Potential Antidote to Intrusive Agencies}

Competition among accreditors, or a multiplicity of approved accreditors, is sometimes suggested as an antidote to overly prescriptive accreditors wielding federal authority. ${ }^{55}$ "Competition" among educational accrediting agencies is a term in need of definition. Competition could take several forms, some desirable or at least neutral from a public policy perspective, and some contrary to the public interest. Thus, if those accrediting agencies that accredit for-profit trade schools compete for membership fees by lowering their standards to permit institutions that do not provide proper training to participate in federal programs, the federal interests in protecting taxpayers and students are sacrificed. On the other hand, accrediting agencies could compete by seeking to make membership in their organization the preeminent symbol of high quality. That could benefit students and taxpayers. Similarly, agencies can compete for membership by offering more helpful advice and scrutiny than their competitors. The government should establish no barriers to that.

Whether competition in accreditation develops, and if it does, whether it is helpful or harmful to students and taxpayers, depends significantly on the regulatory context and the type of accrediting agency. For example, by making accreditation a condition of eligibility, the federal government created a climate in which for-profit schools wholly dependent on federal student aid dollars helped form, and determine the standards of, new accrediting agencies. This led to a troubling form of competition-competition for the lowest standards. Where a proprietary school failed to satisfy the minimum requirements of one such agency, it could turn to one with even lower standards. ${ }^{56}$

On the other hand, accreditation jumping has not been a problem in the collegiate sector. Yet even in that sector, the Department has long been reluctant to recognize new agencies that are not accepted by their more

53. Section of Legal Educ. And Admissions to the Bar, AMERICAN Bar Ass'N, A ReVIEW OF LEGAL EDUCATION IN THE UNITED STATES FALL 1990: LAW SCHOOLS AND BAR ADMISSION REQUIREMENTS 75-82 (1991).

54. See infra part VII.B.2.

55. See, e.g., Clark C. Havighurst, Accreditation Competition Needed, MODERn HEALTHCARE, Nov. 16,1992 , at 24 .

56. See, e.g., NUNN COMMITTEE REPORT, supra note 2, at 17-18. 
established competitors. In reviewing a petition for initial recognition by an accrediting agency, historical departmental practice has been to place great weight on whether other recognized agencies recommend the new applicant. ${ }^{57}$ While this should certainly be considered, over-reliance on this factor is neither necessary nor consistent with preservation of institutional freedom. Acceptance in a field can also be proven by respected experts, professional associations, institutions, and licensing officials.

Prior to 1988 , the Department's recognition regulations specifically provided that it was unlikely that more than one agency could qualify for recognition in a defined geographical jurisdiction or in a defined field of program specialization. ${ }^{58}$ The regulations also stated that if two agencies with overlapping jurisdiction seek recognition, they each must demonstrate "need" for their activities. $^{59}$ In 1988, Secretary Bennett deleted that provision, stating:

With regard to the use of the regulations to limit proliferation and fragmentation in accreditation, the Secretary determined that arbitrarily limiting the number of accrediting bodies serves no educational purpose. The Secretary wishes to foster appropriate competition among accrediting bodies and does not wish to see the recognition process used in such a way as to create a monopoly in any educational field. ${ }^{6}$

Secretary Alexander announced in his final Middle States decision that he would read the Department's regulations to permit recognition of newly formed competing accrediting agencies, provided those agencies meet rigorous standards of reliability. ${ }^{61}$ Thus, future Middle States-type controversies, or other intrusive prescriptions by accrediting agencies that endanger institutional autonomy, might be solved by permitting or encouraging the emergence of competing collegiate accrediting agencies. ${ }^{62}$

Notwithstanding the change in presidential administrations, there is continued interest in some segments of the academic world in competition among accrediting agencies. For example, a new, specialized accrediting association for undergraduate liberal arts colleges has been founded by academics who wish to reestablish the primacy of traditional liberal arts

57. See, e.g., U.S. Dept. of Education, Office of the Secretary of Education, Decision Regarding Middle States (Apr. 1992) (copy on file with author) [hereinafter Decision Regarding Middle States]; 53 Fed. Reg. 25,096 (1988).

58. E.g., 45 C.F.R. § 149.5 (1974) (repealed 1988); 39 Fed. Reg. 30,042 (1974) (repealed 1988).

59. See, e.g., 39 Fed Reg. 30,042 (1974) (repealed 1988); 53 Fed. Reg. 25,095 (1988) (Some commentators opposed removal of this requirement for a showing of "need" for more than one recognized agency where accrediting agencies compete.).

60. 53 Fed. Reg. 25,096 (1988).

61. See Decision Regarding Middle States, supra note 57; see also U.S. Dept. of Education, Office of the General Counsel, Legal Opinion Concerning the Requirements for Recognition of Newly Formed Accrediting Agencies (Apr. 1992) (on file with author).

62. Similarly, the recently adopted accreditation regulations do not require acceptance by recognized agencies as a condition of recognition. See 34 C.F.R. $\$ 602.22$ (1994); 59 Fed. Reg. 22,271 (1994) ("The Secretary believes that agencies should not be required to demonstrate acceptance by recognized accrediting agencies but may certainly do so in their application for recognition if they wish."). 
education. ${ }^{63}$ Named the American Academy for Liberal Education, it plans to establish high standards, apply them, and ultimately seek Department of Education recognition. ${ }^{64}$

Despite this development, the idea that overlapping accrediting agencies with distinctive philosophies and approaches could enrich higher education is not widely accepted in higher education circles. ${ }^{65}$ Accrediting agencies themselves are generally averse to rivals. Many believe a new accrediting agency should be welcomed into the system only if there is a "need" for that agency, that is, if it accredits types of institutions or programs not within the scope of review of the established agencies. ${ }^{66}$

College presidents sometimes oppose competition on the ground that colleges already have to cope with too many accrediting agencies, because of the number of programmatic or specialized agencies. ${ }^{67}$ This may be a valid concern, but it should be addressed not by government mandate, but by letting each school choose the services worth paying for.

In sum, competition in accreditation, or the availability of alternative accreditors for a school, may undermine the federal government's interests in certain instances but not others. On occasion, proprietary schools switched accreditors when they found themselves in difficulty with their current accrediting agency. ${ }^{68}$ Such "accreditation shopping" may undermine the integrity of federal gatekeeping and drive accreditation standards to the lowest common denominator. However, the fundamental problem is not schools changing accreditors; the problem is the recognition of agencies with low standards or lax enforcement. Barring schools from changing accreditors for purposes of federal eligibility may be a way to reduce the incentives for agencies to compete by lowering their standards, but it comes with a cost to institutional autonomy, particularly in the collegiate sector. This is an area in which the view that has long held sway in Congress-that all postsecondary educational institutions must necessarily exist under the same regulatory rules-is counterproductive. Distinguishing the proprietary and vocational sectors from the collegiate sector would enable the federal government to strike a better

63. Anthony DePalma, Traditionalist Scholars Plan to Rate Liberal Arts Colleges, N.Y. TIMES, Mar. 3,1993 , at B13.

64. The standards proposed include asserting the central importance of teaching over other activities, including research, and having senior faculty teach introductory and lower level courses. Id.

65. In late 1991 and early 1992, the National Advisory Committee on Accreditation and Instutional Eligibility invited several higher education leaders to participate in a roundtable discussion of accrediting agencies and their role in determining federal eligibility. See infra text accompanying notes 82-84. The observations made in text regarding the views of the higher education community are based in large measure on the author's participation in those roundtable discussions.

66. See supra note 64; see also supra note 58.

67. See supra note 64 .

68. See, e.g., NUNN COMMITTEE REPORT, supra note 2, at 17-18 (citing "accreditation jumping" of Culinary School of Washington). 
balance between preservation of rigorous accreditation standards and protection of institutional autonomy. ${ }^{69}$

\section{$\mathrm{V}$}

\section{Heightened Department SCRUTINy OF ProprietaRy SCHOOL AGENCIES}

Concurrently with its review of Middle States's petition for renewed recognition, the Department of Education embarked on a much tougher review of trade-school accrediting agencies, ${ }^{70}$ which vigorously resisted such scrutiny. ${ }^{71}$

The impetus for the Department's action was clear. Defaults on federally guaranteed student loans had reached about $\$ 3$ billion per year, undermining the foundations of that vital student aid program. ${ }^{72}$ Lack of quality control by accrediting agencies in the vocational sector was believed to be a significant contributor to that problem. Moreover, the expenditure of federal grant money at schools that fail to provide quality training was an equally serious, though less obvious, problem. ${ }^{73}$ Therefore, the Department increased its scrutiny of the vocational school accrediting agencies.

As part of this tougher approach, the Department began gauging agencies on their effectiveness in reviewing and dealing with institutions' default rates, student aid program problems as revealed in audits, and poor student outcomes such as poor performance regarding course completion, job placement, and licensing rates. Some members of the accreditation community questioned whether this initiative was within the Department's statutory and regulatory authority. ${ }^{74}$

69. The disparity between default rates at proprietary schools and default rates at other schools is quite striking, see infra note 72 , and supports the need for distinguishing among the various sectors of postsecondary education. The preamble to the regulations proposed to implement the 1992 HEA takes the opposite view. There the Department states: "[T]he abuses have been found in all types of institutions participating in SFA [student financial aid] programs, including those in the private nonprofit and public sectors of higher education as well as those in the proprietary sector." 59 Fed. Reg. 3578 (1994); see also id. at 22,264 (final regulations). That statement is true but does not undermine the case for differential regulation based on the relative incidence of abuses in the various sectors.

70. See, e.g., U.S. Department of Education, Second Supplemental Staff Report to the National Advisory Committee: National Accrediting Commission of Cosmetology Arts and Sciences (Jan. 21, 1992) (on file with author).

71. For example, the accrediting agency for cosmetology argued before the National Advisory Committee that the staff report referenced in note 70, 59 Fed. Reg. 3578 (1994), exceeded the Department's legal authority by considering such matters as default rates.

72. During the latter part of President Bush's Administration, default rates finally began to decline. The default rate for fiscal year 1991, the latest year for which the Department has figures, stands at $17.5 \%$, down from the $22 \%$ default rate recorded in fiscal year 1990 . ED Figures Show Student Default Rates Are Down, EDUC. DAILY, July 9, 1993, at 3. Proprietary schools averaged a 35.9\% default rate, public institutions averaged $8.4 \%$, and private nonprofit institutions averaged $6.5 \%$. Id. at 4 .

73. Senator Nunn's Subcommittee recently held hearings to expose abuses in the Pell Grant program. Hearing on Abuses in Federal Student Grant Programs Before the Permanent Subcomm. on Investigations of the Senate Comm. on Governmental Affairs, 103d Cong., 1st Sess. 1 (1993).

74. See, e.g., note 71 supra. 
The Department determined that high default rates and other student aid program problems indicated (but did not prove) the existence of problems in quality of instruction, administrative capacity, and financial stability. As areas that accrediting agencies generally review, the latter constituted fair game for the Department to consider under then-existing recognition regulations. ${ }^{75}$ Moreover, the Department's regulations required review of an agency's consistency in enforcing its own standards, and some agencies were explicitly adopting standards that assessed loan defaults and student aid administration.

Furthermore, the Department determined to examine not only the soundness of the written procedures adopted by an agency, but the results achieved-particularly whether the agency has accredited schools that fail to provide quality training and whether it has acted promptly to withdraw accreditation when appropriate. ${ }^{76}$ Thus, the statutory and regulatory standard of "reliability" was given substantive content. The question was not simply "did the agency on paper have adequate processes and procedures for examining the institutions in various areas?" but "did the agency have a generally reliable track record in making accreditation decisions?"

While the emphasis on results was an expansion of the Department's traditional procedure-oriented approach, it was sufficiently faithful to the language and purpose of the statute and regulations that a court probably would have sustained it. ${ }^{77}$ We shall never know for certain, however, because the 1992 HEA specifically required the recognized accrediting agencies, and the Secretary, to focus on outcomes, defaults, and program administration issues, among others. ${ }^{78}$ Thus, departmental review of accreditors' practices as they affect federal taxpayers' interests is here to stay. Before briefly examining the 1992 HEA, this article will discuss various alternatives to basing eligibility on accreditation.

\section{VI}

\section{REEXAMINING THE LINK BETWEEN ACCREDITATION AND ELIGIBILITY}

One possible solution to the dual problems of lax accreditation in the trade school sector and intrusive accreditation in the collegiate sector is to divorce eligibility from accreditation. Responsible observers have recommended such a solution. In 1971, Secretary of Health, Education and Welfare Finch established a committee chaired by Frank Newman, then of Stanford and now of the Education Commission of the States, to examine institutional eligibility.

75. See, e.g., 34 C.F.R. $\$ 602.16$ (1993).

76. See, e.g., U.S. Department of Education Staff Report to the National Advisory Committee: National Accrediting Commission of Cosmetology Arts and Sciences 2 (1991) (copy on file with author) (citing, inter alia, 34 C.F.R. $\$ 602.10(a)$ ).

77. For a rare example of a judicial challenge to a Secretarial recognition decision, see Sherman College of Straight Chiropractic v. United States Comm'r of Educ., 493 F. Supp. 976 (D.D.C. 1980) (reviewing Secretarial recognition decision for compliance with the Adminstrative Procedure Act).

78. See infra part VII.A. 
A draft of the Committee's report circulated in 1971 and called for sweeping changes in determining federal eligibility. ${ }^{79}$

The Newman Committee recommended that standards of eligibility be nationally standardized and not involve standards of educational quality. Instead, the Committee suggested that eligibility be based on a finding that an institution is financially responsible and honest and that it conducts a program of some educational value for some clients. The federal government could recognize accrediting agencies and other organizations as authorities on whether institutions meet these federal eligibility standards. Alternatively, a national committee could grant eligibility directly. As an additional condition of eligibility, all postsecondary institutions would be required to prepare an accurate "prospectus" describing the institution.

The Newman Committee's recommendations did not go forward in Congress. Nor does the Committee's recommendation of a comprehensive, uniform, government-controlled system of eligibility for postsecondary institutions seem to be sound. While the eligibility standards proposed by the Newman Committee were modest, they represented the potential start of a comprehensive national system of accreditation under government control, something the educational community strongly opposed..$^{80}$ But elements of the Newman Committee's recommendations did resurface in the 1992 HEA-particularly the national setting of standards in specified areas that must be reliably applied by accrediting agencies seeking federal recognition. ${ }^{81}$

Secretary Alexander initiated another effort at fundamental reexamination of the relationship between eligibility and accreditation. He asked the National Advisory Committee to analyze whether the link between federal eligibility and accreditation should be severed altogether. ${ }^{82} \mathrm{He}$ also asked if higher education institutions of unquestioned academic quality should be eligible to participate in federal aid programs without having to demonstrate their accreditation. ${ }^{83}$ Focusing the reviewing resources of private accreditation on those institutions whose federal eligibility should be open to reasonable question would have the advantages of protecting federal interests and academic freedom. However, implementing such a system would raise difficult questions. What standards would determine which institutions get an exemption? Who would determine this and how frequently?. And what method-accreditation, state review,

79. "Accreditation and Institutional Eligibility," November 1971 draft report of the H.E.W. task force, chaired by Frank Newman.

80. As Harold Orlans put it, "[t]he educational community, like the citizenry at large, prefers a good deal of private chaos to government-imposed order, and it gets a good deal of what it wants." Orlans, supra note 4, at 196.

81. See infra part VII.

82. Alexander, supra note 37 , at 17.

83. Id. at 15; Letter from Lamar Alexander, U.S. Secretary of Education, to Professor Martin Trow, Chairman of the National Adivsory Committee on Accreditation and Institutional Eligibility 2-3 (Nov. 14,1991 ) (on file with author). 
federal review, or some combination thereof-should determine eligibility for schools not receiving an automatic exemption?

The idea of severing accreditation from federal aid eligibility was also considered during congressional debate on reauthorization of the HEA. The House's 1992 HEA bill proposed to return accreditation to its voluntary roots by severing the link between accreditation and eligibility, instead relying on strengthened state review as well as financial certification review by the Department $^{84}$ This proposal was developed by the House Education and Labor Committee in response to its dissatisfaction with the accreditation community's unwillingness to shoulder any responsibility for improving the administration of the federal student aid program. The Committee report stated:

The Committee heard testimony that the current accreditation process was ineffective.

The Inspector General at the Department of Education testified that "billions of dollars available to students each year through loans and grants are at risk, in part because the recognition process does not assure that the accrediting agencies use appropriate and effective policies to accredit schools.

The Committee received no recommendations from the higher education community for the improvement of this process. Since accrediting bodies are private, non-government organizations the Committee is reluctant to impose any standards on them without their recommendations. Without such standards, the Committee does not believe the current system is effective. ${ }^{85}$

Thus, the House Committee called the bluff of those members of the accrediting community who both decried government oversight of accrediting agencies and professed indifference to the agencies' unbidden role as federal gatekeepers.

The reaction of the higher education community to the House Committee proposal was as anticipated. The higher education lobbies vigorously opposed removing the link between accreditation and federal eligibility. ${ }^{86}$ Part of the opposition arose from colleges and universities, which were understandably worried about greater state and federal government oversight of academic institutions. ${ }^{87}$ But the objections of the accrediting agencies themselves were more self-serving. While they had long expressed indifference to or disdain for the federal government's determination to rely on their decisions, in reality they understood that the interest of schools in their services would diminish significantly if eligibility were severed from accreditation.

The Bush Administration suggested in its report on the House bill ${ }^{88}$ that Congress distinguish vocational institutions from collegiate institutions by increasing the states' role and eliminating federal reliance on accreditation in the vocational sector, while continuing to rely on accreditation in the collegiate

84. H.R. REP. No. 447, 102d Cong., 2d Sess. 74 (1992), reprinted in 1992 U.S.C.C.A.N. 334, 407.

85. Id. at 74-75, 1992 U.S.C.C.A.N at 407-08.

86. Based on the author's personal participation in the process.

87. Id.

88. See Letter from Secretary Alexander to Chairman William D. Ford, Appendix A, at 17-19 (Oct. $21,1991)$. 
sector. That idea went nowhere in the face of the intractable opposition of Representative William Ford, Chairman of the House Education and Labor Committee, to distinguishing vocational institutions from collegiate ones, or public and nonprofit institutions from proprietary ones. Chairman Ford believed any regulatory distinctions would amount to unfair discrimination against trade schools. ${ }^{89}$

The threat of removing federal authority from accrediting agencies ultimately resulted in a compromise: Congress retained the link between accreditation and eligibility but required accrediting agencies to be more attentive to their federal gatekeeping role. ${ }^{90}$ Recognized agencies are to be held accountable to more clearly defined regulatory interests set out in the statute and assessed by the Secretary of Education. ${ }^{91}$ In short, as discussed below, accrediting agencies that seek federal recognition must now meet a number of specific statutory requirements. ${ }^{92}$

VII

\section{The ACCREditation Provisions of the Higher EdUCATION AMENDMENTS OF 1992}

\section{A. A Brief Overview}

Section 496 of the 1992 HEA requires that, in order to be recognized by the Secretary of Education, an accrediting agency must have standards for assessing several defined areas of an institution's operations, including the conventional subjects of accrediting agency review, such as curricula and faculty and facilities, as well as areas of importance to federal program concerns, including default rates, student achievement rates in relating to institutional mission, records of student complaints, reasonableness of fees in relation to credentials offered, and compliance with federal student aid program responsibilities. ${ }^{93}$ Section 496 also requires accrediting agencies to meet standards of independence and to use

89. Chairman Ford has recently announced that he will retire from Congress at the end of 1994. House Panel Faces Major Shuffle after Ford Leaves Next Year, Educ. DAILY, Jan. 28, 1994, at 1. That fact, as well as the changes wrought by the 1994 elections, may auger well for the future prospects of differential regulations by sector.

90. See 20 U.S.C. $\S 1099 b$ (Supp. IV 1992).

91. Id. $\$ 1099 \mathrm{~b}(\mathrm{a})$.

92. The former President of COPA, Dr. Kenneth Perrin, has observed that while accrediting agencies lobbied hard to be retained as gatekeepers in the 1992 HEA, the decisive effort was made by college presidents who, though critical of accreditation, loathed the idea of increased state oversight as a replacement for accreditation. Kenneth Perrin, Address to COPA Membership (Apr. 6, 1993). He views the $1992 \mathrm{HEA}$ as buying time for accreditation to improve and prove its value. His address concluded:

If we don't use this time well, I believe accreditation can and will be replaced as a major force in

American higher education. In its place I see state oversight, national assessment and such processes as TQM. If peer review is replaced by something less efficient and even more costly, then Id. the fault will be our's and no one else's.

93. 20 U.S.C. $\S 1099$ b (Supp. IV 1992). 
certain operating procedures, including review of "teach-out" agreements to protect students in the event a school closes and review within six months of new branch campuses or of ownership changes. ${ }^{94}$ It requires each agency to maintain public information about its accreditation processes and to make public the schools being considered for accreditation. ${ }^{95}$ It also requires some unannounced reviews by agencies of vocational schools and by the Education Department of accrediting agencies. ${ }^{96}$

The 1992 HEA is predominantly against competition among accrediting agencies. ${ }^{97}$ It precludes dual accreditation for federal eligibility purposes. ${ }^{98}$ It also precludes certification of a school that has had its accreditation revoked or has withdrawn voluntarily after an agency has issued a show cause or suspension order. ${ }^{99}$ This prevents abusive "accreditation shopping," which has been a problem in the trade school sector, but also impedes a solid institution's ability to leave a philosophically incompatible agency. There is an exception to this rule for institutions that lose accreditation or withdraw due to religious mission or affiliation. ${ }^{100}$ No such exception exists for secular institutions that differ with an agency's diversity or other controversial standards. ${ }^{101}$

Furthermore, even when a school switches accrediting agencies without any formal pressure from its prior accreditor, the school must establish to the Secretary of Education's satisfaction "reasonable cause" for changing agencies. ${ }^{102}$

In addition, the 1992 HEA removes the "three-letter" exception to accreditation for purposes of federal eligibility. ${ }^{103}$ The removal of this exception tightens the relationship between federal aid and accrediting agency determinations. ${ }^{104}$

94. Id.

95. Id.

96. Id.

97. Id.

98. Id. § $1099 \mathrm{~b}(\mathrm{~h}),(\mathrm{i}),(\mathrm{j})$.

99. Id. $\$ 1099 \mathrm{~b}(\mathrm{j})$.

100. Id. § $1099 \mathrm{~b}(\mathrm{k})$.

101. Id.

102. Id. \$ $1099 \mathrm{~b}(\mathrm{i})$.

103. If three accredited institutions in the collegiate sector accepted another unaccredited institution's credits, the unaccredited collegiate institution was, under prior law, eligible to participate in certain federal student aid programs. See, e.g., Pub. L. No. 99-498, \$435(b)(5), 100 Stat. 1268, 1409 (1986), repealed by $\S 427$ (b)(1) of Higher Education Amendments of 1992. The Higher Education Technical Amendments of 1993, Pub. L. No. 103-208, 107 Stat. 2457 (codified as amended in scattered sections of 20 U.S.C.), provide for preservation of the eligibility of institutions which had been eligible pursuant to transfer of credit and who thereafter timely apply for and receive accreditation or preaccreditation status. 20 U.S.C.A. $\$ 1141$ note (West Supp. 1994).

104. It also undercuts the rationale of decisions which have in the past protected the accrediting agencies from antitrust scrutiny. Cf. Marjorie Webster Junior College v. Middle States, 432 F.2d 650 (D.C. Cir.), cert. denied, 400 U.S. 965 (1970). In holding antitrust laws inapplicable to Middle States's rule of refusing to consider proprietary schools for accreditation, the Marjorie Webster court relied in part on the existence of the three-letter rule as an alternative to accreditation for federal eligibility. Id. at $656 \mathrm{n} .32$. Marjorie Webster primarily involved reliance on the notion that regulation of educational interests does not involve a commercial restraint of trade subject to the Sherman Act. See id. at 654-55. 


\section{B. Dealing With An Accrediting Agency's Determination to Act as a Diversity Policeman Under the 1992 HEA}

1. The Statutory Issue. The Middle States diversity controversy would present an interesting question of statutory construction under the 1992 HEA. section 496 requires an agency seeking recognition to have standards on such general issues as "curricula," "faculty," and "student support services."105 Moreover, a recognized agency must consistently apply and enforce standards that ensure that the programs are of sufficient quality to achieve "the stated objective for which the courses or programs are offered."106 Thus, the Secretary has gained statutory authority to require and review the standards of recognized accrediting agencies in several specified areas. A recognized accrediting agency may adopt additional standards apart from the subjects listed in the statute. The Secretary cannot disapprove or approve agencies on the basis of additional standards not provided for in section $496 .{ }^{107}$ Thus, section 496(g) prohibits the Secretary from establishing standards for accrediting agencies not required by section 496 but allows agencies to adopt additional standards not provided for in the section.

The question arises whether the Secretary of Education is authorized to scrutinize an agency's application of diversity criteria within any of the subjects on which accreditation standards are required and Secretarial review authorized. While the Chevron doctrine affords broad judicial deference to agency interpretation, ${ }^{108}$ the text and structure of section 496 appear to indicate that the Secretary of Education should not repeat the Middle States intervention. ${ }^{109}$ The section $496(\mathrm{~g})$ provision expressly refusing to authorize the Secretary to establish additional standards not otherwise provided for by section 496 , but authorizing agencies to establish standards not provided for in the section, ${ }^{110}$ has little meaning unless the Secretary is precluded from considering issues like diversity standards. Stretching the concept of "faculty" standards embodied in section $496(a)(5)^{111}$ to include standards on the racial, ethnic, and gender composition of a faculty might conceivably be sustainable if considered in isolation, but there is no analogous category in that section authorizing

That notion, and the related concept of a "learned profession" exemption from the antitrust laws, has been rejected by later decisions. E.g., National Soc'y of Professional Eng'rs v. United States, 435 U.S. 679 (1978); see also Massachusetts School of Law at Andover, Inc. v. ABA, 855 F. Supp. 108 (E.D. Pa. 1994) (denying motion to dismiss antitrust challenge to denial of accreditation).

105. 20 U.S.C. $\S 1099$ b(a)(5) (Supp. IV 1992).

106. Id. \& $1099 \mathrm{~b}(\mathrm{a})(4)$.

107. Id. § $1099 \mathrm{~b}(\mathrm{~g})$.

108. Chevron U.S.A. Inc. v. Natural Resources Defense Council, Inc., 467 U.S. 837 (1984). Of course, despite Chevron, judges continue to display great differences in the extent to which they defer to agency interpretations. See, e.g., Dole v. United Steelworkers of Am., 494 U.S. 26 (1990).

109. 20 U.S.C. $\$ \$ 1099 b(g)$, (k) (Supp. IV 1992).

110. Id. $\$ 1099 \mathrm{~b}(\mathrm{~g})$.

111. Id. \& $1099 \mathrm{~b}(\mathrm{a})(5)(\mathrm{B})$. 
Secretarial review of diversity standards for administrators, governing boards, and students. There is no reason to suppose that Congress intended to authorize the Secretary of Education to review faculty diversity standards adopted by accrediting agencies but not other diversity standards. The structure of the statute thus suggests that an agency's demographic diversity standards is a subject on which the Secretary should not base recognition decisions.

The Department could maintain that section 496(g) should be narrowly limited to its precise language. It merely says the Secretary may not require accrediting agencies to establish accreditation standards on topics not listed by the statute, and may not prohibit agencies from adopting additional standards not provided for in section $496 .{ }^{112}$ One could argue that this amounts to no more than a reaffirmation of section 103 of the DEOA, prohibiting federal control over accrediting agencies. ${ }^{113}$ Under this reading, the Secretary could still decline to recognize an agency as reliable due to an agency's standards, or lack thereof, in areas not listed in the statute. However, that reading is not tenable because the only function of the section 496 standards is to govern the recognition process. Those standards are not imposed on accrediting agencies unless they seek Secretarial recognition.

Section 496(k) reinforces the conclusion that section 496 does not authorize Department review of diversity standards in the recognition process. Section 496(k) permits an institution that has lost accreditation to remain eligible for a period of time sufficient to obtain alternative accreditation if the Secretary determines the reason the institution lost accreditation is related to the religious mission of the school and not to the accreditation standards provided for in section $496{ }^{114}$ This provision, proposed in the House-Senate conference by the late Representative Paul Henry of Michigan and enacted in response to Middle States's actions regarding Westminster, ${ }^{115}$ indicates that Congress generally considered diversity standards not to be encompassed within section 496. Instead of authorizing Secretarial review of diversity standards, Congress decided on an alternative approach to protection of institutional autonomy. The Secretary was authorized to preserve a religious institution's eligibility without embroiling the Secretary in evaluation of the agency's diversity standards. ${ }^{116}$

112. Id. $\S 1099 \mathrm{~b}(\mathrm{~g})$.

113. Id. \& 3403(b) (1988).

114. Id. \& 1099b(k) (Supp. IV 1992).

115. Based on the author's personal participation in the process.

116. In the Conference Report on the 1992 Amendments, H. REP. No. 630, 102d Cong. 2d Sess. 525 (1992), reprinted in 1992 U.S.C.C.A.N 640, this provision is described as authorizing the Secretary to extend the "eligibility of an institution whose accreditation was revoked because of a religious mission or for a reason unrelated to the accreditation standards established in this Act in order for the institution to become accredited by another accrediting body." This description would indicate that the 1992 HEA would allow the Secretary to extend the eligibility of a secular institution which has lost eligibility due to a diversity standard if such standard is not provided for in the statute. But the statutory text itself permits the Secretary to extend eligibility only if the reason for withdrawal of accreditation "is related to the religious mission or affiliation of the institution" and is "not related to accreditation standards provided for in this section." 20 U.S.C. \& 1099b(k) (Supp. IV 1992). Thus, since the statutory text governs, the Secretary could, if a new Middle States case should arise, extend the 
Moreover, an interpretation of section 496 that authorized the Secretary to deny recognition based on an agency's intrusive use of diversity criteria would also authorize the Secretary to mandate an agency's use of diversity criteria. There is nothing in the language, structure, or history of section 496 to suggest that the Secretary of Education was authorized to establish uniform national standards on diversity in higher education.

Thus, the soundest interpretation of section 496 is that, as a statutory matter, the Secretary of Education cannot grant or deny recognition based on an agency's adoption or application of diversity standards. The language and structure of the statute so indicates, and judicial deference under Chevron stops short of permitting the Department to interpret the statute to reach a policy outcome that Congress rejected.

2. The Constitutional Issue. The conclusion that the 1992 HEA does not authorize the Secretary of Education to deny recognition based on an accrediting agency's intrusive use of standards for diversity, or other subjects not provided for in section 496, also raises a constitutional issue. A serious First Amendment problem arises in recognizing an agency and giving it authority over federal student aid eligibility that it then uses to infringe an institution's academic freedom. Alternative forms of eligibility, such as an alternative accreditor, may mitigate the constitutional problem, but current law poses serious statutory impediments to changing accreditors. ${ }^{117}$

In theory, there are at least two ways to protect a postsecondary institution's first amendment liberty: through the Department's recognition process or through litigation challenging an agency's particular decisions. Judicial intervention in particular cases is the sounder option for an aggrieved institution, since Congress intended that the Department not bring such issues into the recognition process. Moreover, the federal courts are more suitable than the Department as a forum for resolution of contested facts and disputed issues of constitutional law. Will the courts entertain such constitutional challenges?

Existing precedent generally holds that a recognized accrediting agency's denial of accreditation is not state action rendering the denial subject to constitutional challenge. ${ }^{118}$ The conventional analysis has been that the nexus

eligibility of a Westminster Seminary but not a Baruch College. Nor, based on my own discussions with the staff of Representative Henry at the time, does it appear likely that the text failed to carry out Congress's intent. The conferees understood that this language would protect only religious institutions. The conference report language simply used the wrong conjunction.

117. See supra notes $97-104$ and accompanying text.

118. See, e.g., Medical Inst. of Minn. v. National Ass'n of Trade and Technical Sch., 817 F.2d 1310 (8th Cir. 1987); American Technical College v. Accrediting Council for Continuing Educ. and Training, No. 92 C 2635, 1993 U.S. Dist. LEXIS 2581 (N.D. Ill. Mar. 3, 1993); Peoria Sch. of Business, Inc. v. Accrediting Council for Continuing Educ., 805 F. Supp. 579 (N.D. Ill. 1992); Parsons College v. North Cent. Ass'n of Colleges and Secondary Sch., 271 F. Supp. 65, 70 (N.D. Ill. 1967). See generally, William A. KAPLIN \& J. Philip HUNTER, Comment, The Legal Status of the Educational Accrediting Agency: Problems in Judicial Supervision and Governmental Regulation, 52 Cornell L.Q. 106 (1966). 
between the federal government and the decision of an accrediting agency is not so close that the agency's action may fairly be treated as that of the government, particularly since the federal government's recognition standards did not substantively regulate the accreditation decisionmaking process. Therefore, courts have reviewed the accrediting agencies' decisions under common law standards for procedural regularity, including compliance with the agency's own written procedures, reasonableness, and non-arbitrariness. ${ }^{119}$ But courts have typically deferred to an agency's expertise on educational matters. ${ }^{120}$

The Supreme Court's relevant "state action" precedents also hold that government regulation of a private entity ${ }^{121}$ and adjustment of federal benefits based on a private entity's decisions ${ }^{122}$ are not necessarily sufficient to render the entity's decisions that of the state for constitutional purposes. On the other hand, where the government has acted jointly with a private actor to take the challenged actions, or where the government has provided a rule of decision, state action is likely to be found. ${ }^{123}$

One possible, albeit likely unintended, consequence of the $1992 \mathrm{HEA}$ is to make it more probable that courts will subject the decisions of recognized accrediting agencies to constitutional scrutiny. Instead of merely deciding to base federal eligibility on the independent decisions of accrediting agencies, the 1992 HEA prescribes a number of requirements that agencies must meet and a number of areas in which agencies must use government-approved standards in assessing institutions. Moreover, alternatives to the adverse effect of an agency's decision have been narrowed, in that the three-letter rule exception for eligibility has been removed, and a school cannot simply change accreditors. Under these circumstances, it seems more likely than under current law that the decisions of accrediting agencies constitute "state action" subject to constitutional strictures.

The "state action" issue is moot with respect to the applicability of procedural due process protections under the Fifth Amendment. The 1992 HEA specifically requires a recognized agency to "apply procedures throughout the accrediting process, including evaluation and withdrawal proceedings, that comply with due process," including an opportunity for hearing, right of appeal, and right to counsel. ${ }^{124}$ This statutory protection thus makes the "state action" issue an academic question for purposes of due process protection. It is unclear whether a school will have the right to enforce the procedural command of the statute, since it is directed to the Secretary's recognition of agencies. But since the Secretary must require due process procedures before recognizing an

119. E.g., Wilfred Academy of Hair and Beauty Culture v. Southern Ass'n of Colleges and Sch., 957 F.2d 210 (5th Cir. 1992).

120. See id.

121. Rendell-Baker v. Kohn, 457 U.S. 830 (1982).

122. Blum v. Yaretsky, 457 U.S. 991 (1982).

123. Lugar v. Edmondson Oil Co., 457 U.S. 922 (1982).

124. 20 U.S.C. $\$ 1099 b(a)(6)$ (Supp. IV 1992). 
agency, the existing case law providing that a school can enforce an accrediting agency's written procedures should ensure that procedural protections are enforceable. ${ }^{125}$ On the other hand, a finding of "state action" remains indispensable to the applicability of First Amendment protection.

Under the 1992 HEA, decisions of accrediting agencies are more likely to be deemed governmental actions subject to federal constitutional constraints when they are based on standards promulgated by the Secretary in the areas identified by the statute. Since, as discussed above, diversity is not one of those areas for which the Secretary is to prescribe standards, it is still quite possible that a court would conclude that a denial of accreditation on such a ground is not state action. However, such a result should not mean that the government can terminate eligibility on grounds infringing institutional academic freedom. Instead, an institution that believes the accrediting agency's negative decision has infringed its academic freedom should sue both the agency and the United States. The school should challenge both the accrediting agency's action and the constitutionality of the eligibility termination as an application of the Higher Education Act. One way or another, if there is a First Amendment violation resulting from the combination of the accrediting agency's decision and the Higher Education Act's termination of eligibility in reliance on that decision, it should be subject to judicial review and remediation. ${ }^{126}$

This is not to suggest that the denial of accreditation-and hence eligibility-for failure to satisfy the agency's standards will generally be vulnerable under the First Amendment. Absent content-based regulation, or action that effectively substitutes the agency's goals for the legitimate academic objectives the college has set for itself, courts are apt to defer to accrediting agencies and reject the claim that academic freedom has been unconstitutionally infringed. ${ }^{127}$ However, such First Amendment challenges should be heard and resolved on the merits, not dismissed due to lack of state action.

125. See supra note 119 and accompanying text.

126. A system of private actors making decisions that deprive educational institutions of government benefits also may raise questions under the nondelegation doctrine, a doctrine derived from the separation of powers principles implicit in the Constitution. See generally Harold J. Abramson, A Fifth Branch of Government: The Private Regulators and Their Constitutionality, 16 HASTINGS CONST. L.Q. $165,187-99$ (1989). While the remaining constitutional limits on delegation of legislative or adjudicative authority have not generally barred the government from relying on accrediting agencies' decisions, a serious constitutional issue may exist if the arrangement fails to protect minority interests. See, e.g., Carter v. Carter Coal Co., 298 U.S. 238, 311 (1936); James O. Freedman, Delegation of Power and Institutional Competence, 43 U. CHI. L. REV. 307, 333-34 (1976).

As I understand him, Professor Finkin argues that the 1992 HEA is unconstitutional under the nondelegation doctrine insofar as it precludes Department review of accrediting agency standards not related to the standards provided for in the Act. Finkin, supra note 4, at 117-18. I have less confidence in the vitality of the nondelegation doctrine and tend to think that a court is apt to intervene on constitutional grounds only if the combined result of the statutory scheme and the agency's action is to abridge substantive constitutional rights, such as first amendment freedoms.

127. See University of $\mathrm{Pa}$. v. EEOC, 493 U.S. 182, 197-98 (1990). 
C. Tightened Review of Accreditation in the Vocational Sector Under the Higher Education Amendments of 1992

The central thrust of section 496 of the 1992 HEA is heightened regulation of those agencies that accredit those postsecondary institutions with problems that call into question the wisdom of granting them federal eligibility. For example, the 1992 HEA imposes a requirement that a recognized accrediting agency be independent from any affiliated trade group. ${ }^{128}$ Agencies must now assess issues that affect federal fiscal interests, such as default rates, program length, and tuition and fees in relation to the subject matter taught, student achievement, job placement rates, and compliance with federal program requirements. While these standards authorize the Department to screen out many questionable institutions through the accrediting agency recognition process, the question remains whether the Department will effectively wield the tools Congress has created. ${ }^{129}$

The Education Department's accrediting agency evaluation branch has in the past often approached its function regarding accrediting agencies not as a regulator, but as a collegial peer reviewer. While this approach has been helpful in avoiding undue federal influence over higher education, it has also meant that the recognition process has not been effectively used to promote better "gatekeeping." To cite a startling example, while Department staff has been fairly cautious about initial recognition of an agency, until Secretary Alexander's tenure, no recognized agency had ever been delisted for inadequate performance. ${ }^{130}$ Part of the staff's reluctance to consider derecognition of an agency resulted from the devastating effect on schools' eligibility if their accrediting agency were delisted. ${ }^{131}$ Students and quality institutions could be seriously harmed by such action. Thus, the consequences of derecognition were so severe that the threat of derecognition was not credible.

This "atomic bomb" problem has recently been ameliorated to some extent. The 1992 HEA provides that, upon derecognition of an agency, the Secretary may authorize the continued eligibility of the accredited schools for up to 18 months. ${ }^{132}$ In the fall of 1992, shortly after enactment of the 1992 HEA, Secretary Alexander withdrew the recognition of an agency accrediting schools of chiropractic and exercised his discretion to continue the relevant schools'

128. 20 U.S.C. \& 1099b(a)(3) (Supp. IV 1992).

129. The 1992 HEA also provided for a new system of strengthened state approval and oversight. The Department has recently adopted new regulations for the state postsecondary review program. 34 C.F.R. $\$ 602$ (1994).

130. Of course, agencies have been delisted because they ceased performing certain accrediting activities or because the Department ceased listing agencies where their decisions bore no relationship to federal eligibility. See supra note 16 and accompanying text.

131. Based on the author's experience and discussions with Department staff.

132. 20 U.S.C. $\$ 1099 \mathrm{c}(\mathrm{h})(2)$ (Supp. IV 1992). 
eligibility. ${ }^{133}$ That decision is the first time in Department history that a recognized agency has been delisted. Thus, with this precedent to guide current Secretary of Education William Riley and future secretaries, there is reason to believe that the Department will seriously consider delisting agencies if delisting is consistent with the statutes and regulations governing the recognition process. ${ }^{134}$

Whether the Department will find the 1992 HEA provisions on accreditation an effective tool for dealing with the well-known abuses in the proprietary school sector remains to be seen. The recently adopted regulations attempt to strike a balance between ensuring that federal interests in accreditation are satisfied and avoiding government control of academia. ${ }^{135}$ The statutorily required accreditation standards are stated without elaboration, providing agencies with maximum flexibility. ${ }^{136}$ Representatives of the higher education community have applauded that facet of the regulations. ${ }^{137}$ On the other hand, the regulations provide that the agency must apply standards to ensure that the program or institution is of sufficient quality to achieve its objective. ${ }^{138}$ Therefore, an agency may be held accountable in the recognition process for substandard institutions it has accredited. The recognition process should thus no longer focus exclusively on an agency's procedures. Performance should count. The effectiveness of the Department's accreditation regulations will depend on the skill and determination with which the Department reviews accrediting agencies' performance during the recognition process.

\section{VIII \\ CONCLUSION}

No completely satisfactory solution to the eligibility problem exists. The 1992 HEA is generally an improvement over prior law. It reflects the need to rely on accrediting agencies while holding them more accountable. The Department should continue its recent efforts to focus on substance in reviewing the petitions for recognition of accrediting agencies. The Department should focus most of its limited resources on reviewing agencies that are of most concern to federal program interests-the proprietary sector agencies. The Department should make their renewal applications subject to tough review, and it should delist any agency if its performance as measured against the statutory criteria is weak. Since the Secretary, under the 1992 HEA, can keep a delisted

133. Decision of the Secretary of Education on the Petition for Renewal of Recognition Submitted by the Commission on Accreditation, Straight Chiropractic Academic Standards Association (Sept. 4, 1992) (copy on file with author).

134. Moreover, the 1992 HEA provides a procedure for terminating an agency's recognition prior to its scheduled expiration. 34 C.F.R. $\$ 602.14$ (1994).

135. Id. $\$ 602$.

136. Id. $\$ 602.26$. 6.

137. See Student Aid Players Applaud, Pan Mountain of ED Rules, EDUC. DAILY, May 6, 1994, at 138. 34 C.F.R. $\$ 602.23$ (1994). 
agency's schools eligible for eighteen months, and candidate status with a new agency can be obtained within that time, schools can still be protected. ${ }^{139}$

The Department should also stay aware of any problems caused by accrediting agencies' diversity requirements or other intrusions on academic freedom and institutional autonomy. It should expose abuses to public scrutiny and, if necessary, recommend legislative changes to protect institutional autonomy. But it should not read the HEA to permit it to deny recognition based on an agency's application of diversity criteria. An institution's remedy should be a first amendment challenge in the courts.

139. While this article focuses on accreditation, it goes without saying that the other two components of the triad, federal certification of financial and administrative capacity and state approval, also need to be strengthened. The more attention the Department of Education pays to improving all three elements of federal gatekeeping, the better off students and taxpayers will be. 
